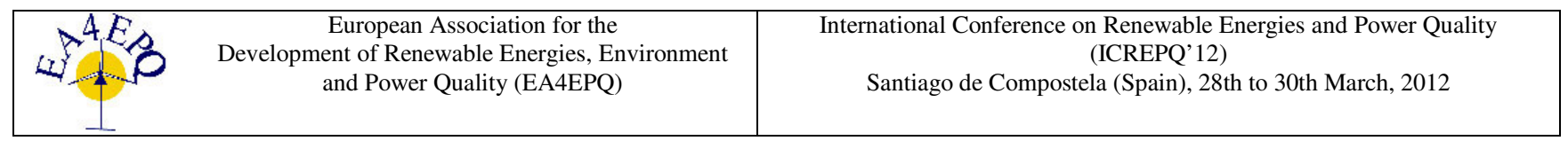

\title{
Biomass Electricity Generation Using Industry Poultry Waste
}

\author{
M. O. Oliveira ${ }^{1-2}$, R. Somariva ${ }^{3}$, O. H. Ando Junior ${ }^{3}$, J. M. Neto ${ }^{3}$, A. S. Bretas ${ }^{2}$, \\ O. E. Perrone ${ }^{1}$, and J. H. Reversat ${ }^{1}$ \\ ${ }^{1}$ Energy Study Center to Development -CEED \\ UNaM, National University of Misiones \\ 327 Juan Manuel de Rosas Street, Oberá -Mnes. (Argentina) \\ Phone/Fax number: +54 3755-422170, e-mail: perrone@fio.unam.edu.ar, hreversat@fio.unam.edu.ar \\ ${ }^{2}$ School of Engineering \\ UFRGS, Federal University of Rio Grande do Sul \\ 103 Osvaldo Aranha Avenue, Porto Alegre -RS (Brazil) \\ Phone/Fax number: +55 51 3308-31.29, e-mail: moliveira@ece.ufrgs.br, abretas@ece.ufrgs.br \\ ${ }^{3}$ Department of Electrical Engineering \\ SATC, Beneficent Association of Santa Catarina Coal Industry \\ 73 Pascoal Meller Street, Criciúma -SC (Brazil) \\ E-mail: rafaelsomariva@gmail.com,oswaldo.junior@satc.edu.br,joao.neto@satc.edu.br
}

\begin{abstract}
This work presents study details of a biomass based electricity generation project. The biomass used was industrial poultry litter. The objective of the work is to contribute to the research of poultry waste use in real life applications. In this sense, a case study is presented. The case study is an aviary industry region of southern Brazil, where is evaluated the technical and economic characteristics of power generation using biomass obtained from poultry litter. Still, it is highlighted the large energy potential and the high poultry litter production in the region, which translates into a important source of raw material for electricity generation, currently not highly explored in Brazil.
\end{abstract}

\section{Key words}

Biomass, renewable energy, electricity generation, poultry litter, green energy.

\section{Introduction}

The increase of energy consumption and the growing concern for environmental preservation along with the concept of distributed generation motivates the search for new renewable sources for power generation. Among the sources with great potential for electricity generation, the biomass energy has an important role in the world energy matrix. Currently the largest consumers of biomass based energy are the developing countries, where participation in the energy matrix reaches $40 \%$. In the world, biomass accounts for 10-14\% of energy supply [1].

Environmental issues are among the factors that support the growing interest in biomass energy in the world. The last is more attractive and has gained worldwide attention for being the most renewable and provide a balance of zero $\mathrm{CO} 2$, based on sustainable use [2]-[3].

All biological organisms that can be tapped as energy sources are called biomass. If biomass is burned efficiently, there is production of carbon dioxide and water, therefore, the process is cyclical and it can be stated that biomass is a renewable resource

The most popular forms of biomass are wood and its residues, waste generated by agriculture, agribusiness and animal husbandry, energy forests and municipal solid waste [4]. The agro-industrial residues are more readily accessible and cheaper forms of biomass available nowadays. The biomass resulting from the rejected parts of grains, as straw and peel of rice, corn, wheat, soy, all great cultivations in Brazil, has the potential to be used as energy sources. On the other hand, it is know that Brazil is a major world aviary producer. Thus, the poultry litter is other type of waste available, which is a material distributed in poultry shed to serve as a bed for animals. The last is obtained from the facilities floor, being composed of aviary excreta, uneaten feed and bird feathers.

Thus, motivated by this challenge, this paper has the intention to contribute to the study of including this type of biomass in the Brazilian energy matrix. In addition, the study of technical and economic feasibility of various technological routes related to energy production, using the poultry litter (biomass) will provide a starting point for future projects in this area. Therefore, people will use this new resource to meet growing electricity demand and contribute significantly to environmental preservation. 


\section{Energy Supply in Brazil}

The biomass use in power generation is growing in Brazil, mainly in cogeneration systems for industrial and service sectors. The large hydro power participation and the biomass use in the Brazilian energy matrix represent less $\mathrm{CO} 2$ emissions than the world average of developed countries. Fig. 1 shows the electricity supply in Brazil, where the renewable source represents $85.8 \%$. The biomass energy responds for $28.0 \mathrm{TWh}(5.1 \%)$ of the total energy [5].

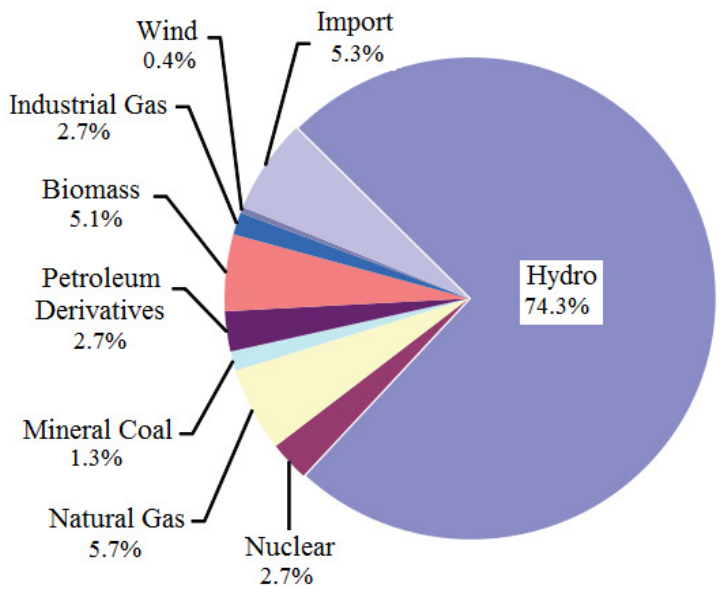

Fig. 1. Brazilian electricity supply.

\section{Poultry Litter}

The poultry litter used in this work is distributed on the floor of sheds that serves for the birds. For this application it can be used various materials such as: wood shavings, peanut hulls, rice hulls, coffee hulls, dry grass and chopped corn cobs [6]. The Fig. 2 shows a typical floor used in sheds.

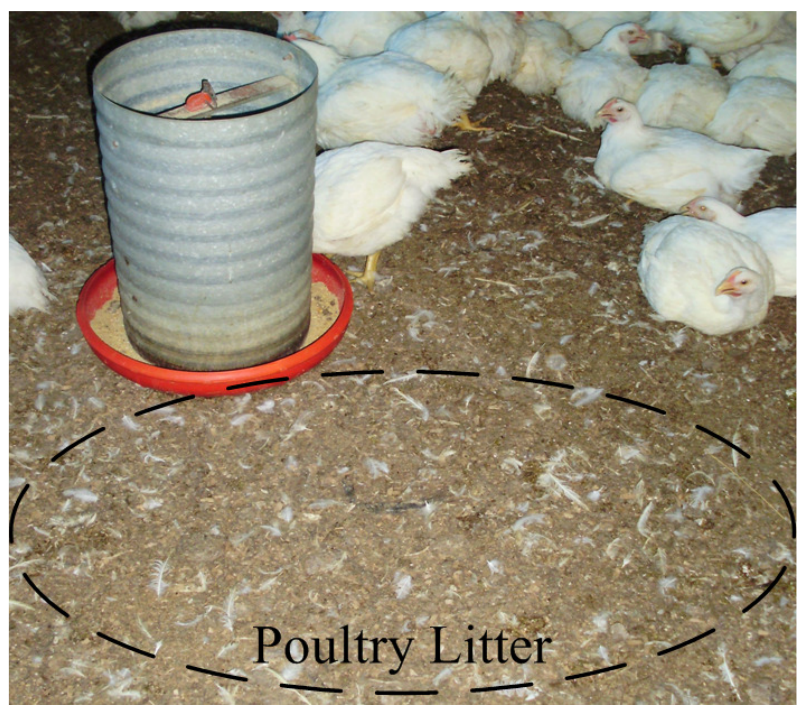

Fig. 2. Floor (bed) used.

The increase of domestic chickens generates large amounts of residues and so it becomes necessary to think about treatment alternatives and/or final destination for this, in order to minimize the impacts caused by it. According to [4], $20 \%$ of global emissions of greenhouse gases come from agriculture activities, where the methane and nitrous oxide are the main gases involved.

The average production of bed is $2.19 \mathrm{~kg}$ per chicken in natural form, ie, without separation of solids and including the humidity percentage [6]. The quantities produced and the characteristics of poultry litter depend on the base material used, the time of year, the creation time and the bird population density [7].

The litter has long been used as a food source for ruminants, however, due to health problems that occurred in Europe in 2001 (as bovine spongiform encephalopathy), the Agriculture Ministry of Brazil banning the use in the litter directed to ruminant feed [6].

\section{A. Chemical Composition}

A destination for poultry waste is to use as fertilizer. If applied correctly, it can produce effective results. However, if the application rate exceeds the retention capacity of the soil or the requirements of the crop, the fertilizer can produce concentration of elements at toxic levels to plants, affecting the water resource and leading to the formation of nitrites.

The main component of pollutants from the waste of birds is nitrogen and phosphorus. One should take into account the possibility of disease transmission due to the fact that these wastes may contain pathogenic microorganisms [7]. Table I presents data of the litter chemical composition, noting that the data refers to a bed of wood shavings after a creating cycle of the 60 days.

Table I. - Chemical composition of poultry litter [5].

\begin{tabular}{|c|c|c|c|}
\hline $\begin{array}{l}\text { Micronutrients } \\
\text { and Metals }\end{array}$ & $\mu \mathrm{g} / \mathrm{g}$ & Macronutrients & $\mu \mathrm{g} / 100 \mathrm{~g}$ \\
\hline Copper $(\mathrm{Cu})$ & 303 & Nitrogen $(\mathrm{N})$ & 2.08 \\
\hline Iron $(\mathrm{Fe})$ & 1,786 & Phosphorus (P) & 1.01 \\
\hline Manganese (Mn) & 294 & Potassium $(\mathrm{K})$ & 2.61 \\
\hline Zinc (Zn) & 217 & Calcium (Ca) & 2.08 \\
\hline Sodium $(\mathrm{Na})$ & 2,629 & Magnesium (Mg) & 0.53 \\
\hline Chromium (Cr) & 5 & Sulfur (S) & 0.028 \\
\hline Lead $(\mathrm{Pb})$ & 22 & & \\
\hline Nickel (Ni) & 2 & & \\
\hline
\end{tabular}

\section{B. Alternative for Energy Generation}

The remaining material in the process of rearing chickens can become a resource or a pollutant. For the environmental impact become minimal, the litter must have proper management and use as best as possible. If not, they can pollute surface and groundwater, can also increase: mineral nutrients, organic substances that require oxygen, suspended matter and sometimes carry pathogenic microorganisms. The creation of chickens can also adversely affect air quality due to emissions of gases such as ammonia, breath odor, and dust production.

One way to mitigate the environmental impact produced in the production of broilers is to use the bed to produce anaerobic or biogas as fuel to generate electricity directly [8]. The calorific value of the poultry litter depends on the humidity level, however, for air dried samples, this value is in the range of 9 to $13.5 \mathrm{MJ} / \mathrm{Kg}$ (about half the coal calorific value) [9]-[10]. 
The biogas generated from poultry litter can be used as energy source in their own farm, where there usage is in heaters to generate thermal energy. The same gas can also be used as fuel for internal combustion engines to generating electricity. The effluents and solid wastes from anaerobic fermentation process can be used as fertilizer for having a high content of protein, vitamins and minerals [8].

There is also the possibility of using the poultry litter as direct fuel for generating electricity for industrial and regional levels. Several technologies are being proposed for use of poultry litter as an energy source, however, most of the results are not in the public domain [11]. Among the processes of converting litter to energy are: coincineration, gasification, direct combustion and anaerobic digestion [6]-[12].

The use of Bio-Digestors for bio-gas production, with animal manure as fertilizer, is a common practice in Brazil, where watersheds that have poultry, swine, chickens and cows in concentrated livestock are the main culture. Electricity Bio-Gas production from poultry litter will be the best option for local economy and environmental safeguard. The optimization of Methane generation process from poultry litter will also be a good financial resource for local population, allowing a change in their economic perspectives, through the employment of bio-gas obtained from their manure and turned into BioFertilizer water and Bio-Electricity. The solid obtained from the digestor can also become other excellent safe agricultural bio-fertilizer, without Nitrogen stabilization and environmental pollution [13].

\section{Case Study}

The aviary industry used in this study is located in the City of Treviso, SC-Brazil. It is a medium-sized aviary unit, which has 150 meters long and 12 meters wide, where they are housed on average 22,000 chickens per batch, which characterizes a population density of birds about 12 birds per square meter. The Fig. 3 shows the avian study.

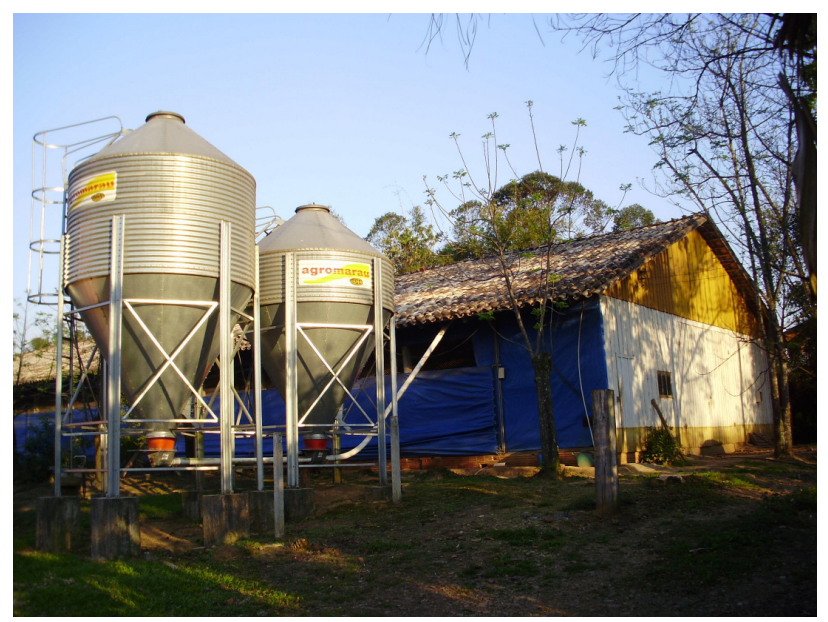

Fig. 3. Avian typical of the region south of Brazil.

\section{A. Electric Characteristics}

The establishment has a bi-phase supply with voltage levels of $220 / 440 \mathrm{~V}$, supplied by a single-bushing transformer. It is worth mentioning that all the major loads are reduced to the aviary engines and lighting. The total installed power is $44.63 \mathrm{KVA}$ for a single-phase system, however, as supply is bi-phase the loads are divided between the phases. On the other hand, the total demand is $31.2 \mathrm{KVA}$.

A chicken creation lot is generally extends over 48 days, where there is a time from one or two weeks between the output and input of the lots. Thus, it can be stated that the complete cycle lasts about 60 days. The average consumption of electricity in a lot is $1,813.5 \mathrm{kWh}$, and the amount paid by the energy in the same period is about of US\$ 265.

\section{B. Potential Electricity Generation}

The density of poultry litter after removal is $400 \mathrm{~kg} / \mathrm{m}^{3}$ [7]. Also, the biogas potential in the poultry litter is $0.1576 \mathrm{~m}^{3} / \mathrm{kg}$, with a calorific value of $6.21 \mathrm{KWh} / \mathrm{m}^{3}$ and the conversion efficiency of biogas to electricity of $25 \%$ [13]. With this date it is possible to estimate the potential power that can be generated from the poultry litter within one batch.

The material used in the bed and the breeding cycles chickens on the same bed can interfered with the potential energy obtained. The potential energy (biogas) of the poultry litter, consisting by wood shavings is $0.1576 \mathrm{~m} 0.1576 \mathrm{~m}^{3} / \mathrm{Kg}$ [10].

Five trucks are removed for each cycle and that the volume transported for a truck is $20 \mathrm{~m}^{3}$. Moreover, the total bed produced in a batch is $100 \mathrm{~m}^{3}$. Thus, multiplying this value by the density of the bed, a total of $40,000 \mathrm{~kg}$ of poultry litter per lot is obtained. If the total mass of bed is multiplied by the potential of biogas $(0.1576$ $\mathrm{m}^{3} / \mathrm{kg}$ ), a total of $6,304 \mathrm{~m}^{3}$ of biogas over the period studied is obtained. This calculation is done using the following equation:

$$
B=n \cdot V \cdot \rho \cdot P_{b}
$$

where, $B$ is the biogas total $\left[\mathrm{m}^{3}\right], \mathrm{n}$ is the truck number, $V$ is the truck volume $\left[\mathrm{m}^{3}\right], \rho$ is the specific mass of the poultry litter $\left[\mathrm{kg} / \mathrm{m}^{3}\right]$ and $P_{b}$ is the potential of biogas $\left[\mathrm{m}^{3} / \mathrm{kg}\right]$.

The calorific value of biogas in the poultry litter is 6.21 $\mathrm{kWh} / \mathrm{m}^{3}$, for an ideal conversion system. Considering that the efficiency of a generator fuelled with biogas is $25 \%$, the real calorific value of biogas is $1.55 \mathrm{kWh} / \mathrm{m}^{3}$. Considering the total of biogas and the calorific value, it can be estimate the amount of electricity generated during the study period (60 day). To this it should be multiplied the amount of biogas $\left(6,304 \mathrm{~m}^{3}\right)$ by the energy potential $\left(1.55 \mathrm{kWh} / \mathrm{m}^{3}\right)$. Thus, using the equation (2) the electricity generated in 60 day can be estimated:

$$
E=B \cdot P_{c r}
$$

where, $E$ is electricity energy [KWh], $B$ is the biogas total $\left[\mathrm{m}^{3}\right]$ and $P_{c r}$ is the calorific value real $\left[\mathrm{KWh} / \mathrm{m}^{3}\right]$.

The electricity generated calculated whit (2) is $9,786.96$ KWh. 


\section{Economic Consideration}

Among the main economic considerations highlighted, is the use of poultry litter as the primary source for electricity generation. Research indicate that the average price of wood shavings in the region is around $12 \mathrm{US} \$ / \mathrm{m}^{3}$. Knowing the amount of wood shavings to be placed in the shed is three trucks, ie, $60 \mathrm{~m}^{3}$, it is concluded that the value of the new bed would be U\$S 706, a value much greater than the savings on electricity.

\section{Southern Brazil Study}

The southern region of Brazil has an important role in the poultry production, where the Santa Catarina state (SC) is the second largest chicken producer of the country. In 2010, the volume of chicken produced in SC was around 907 million units [14]. With this data it is possible to make a comparison with Brazilian states and with states of the other countries. It is know that the United State (U.S.), due to the large amount of waste generated by the poultry industry, has the necessary technology to transform this waste in electricity. Fig. 4 shows a comparison between ten North American states (with the highest chicken production) with the SC.

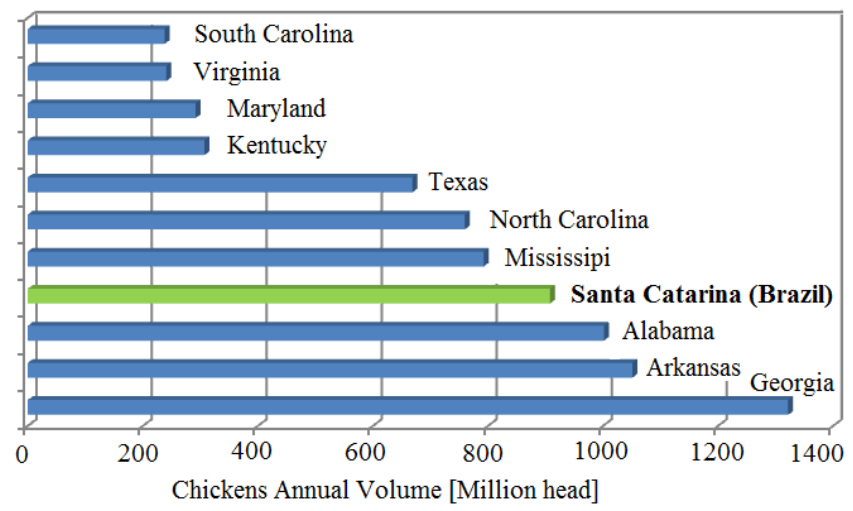

Fig. 4. Comparative Number of Chicken Production (Southerm Brazil).

According to the graph we can say that the SC state has a great potential based on poultry waste. As previously mentioned, in some U.S. states there are already plants generating electricity from poultry litter, for example, the North Carolina.

\section{A. Energy Potential}

The chickens housed number is 24,056,866 head, and taking into account that the bed amount necessary for each chicken is $2,16 \mathrm{~kg}$, it can be calculated a total of $52,684,536.54 \mathrm{~kg}$ of poultry litter.

It is known that the period of raising chickens is 60 days. Thus, it is possible to estimate that in one year there are six lots. Multiplying the total beds numbers by the lots number in one year, it can be estimated that the poultry litter amount generated in one year is $316,107,219.24 \mathrm{~kg}$.

The poultry litter has a calorific value ranging from 9 to $13.5 \mathrm{MJ} / \mathrm{Kg}$. With this average value, it can be estimated that the gross energy potential of the two regions located in Santa Catarina, value of 3,556,206,216.45 MJ/years.
It is know that $1 \mathrm{~W}=1 \mathrm{~J} / \mathrm{s}$, dividing the gross energy potential found previously by the number of seconds in a year, is that the gross energy potential of the southern region of Santa Catarina is approximately of $112.8 \mathrm{MJ} / \mathrm{s}$, ie, $112.8 \mathrm{MW}$. This value was calculated using the following equation:

$$
P B=\frac{m \cdot P_{C}}{k}
$$

where, $P B$ is the gross energy potential $[\mathrm{MW}], m$ is the biomass amount accumulated over one year [Kg/years], $P C$ is average calorific value of poultry litter $[\mathrm{MJ} / \mathrm{Kg}]$ and $k$ is seconds in one year [s/year].

The technical energy potential of the poultry litter can be calculated as:

$$
P T=P B \cdot \eta
$$

where, $P T$ is the technical energy potential [MW], $P B$ is gross energy potential [MW] and $\eta$ is the efficiency of conversion system.

According Sordi et al. [8], the poultry litter can be used as a primary source of energy in the steam motors with turbine coupled to an electric generator. The conversion efficiency of this systems type is between 25 and $35 \%$.

Assuming an average efficiency of $30 \%$, the technical energy potential from the poultry litter in the regons studies is approximately of $34 \mathrm{MW}$. Table II present the considerate and calculate date.

Table II. - Technical Energy Potential to Southern Santa Catarina State.

\begin{tabular}{|l|c|c|}
\hline \multicolumn{3}{|c|}{ Micro-Regions AMREC and AMESC } \\
\hline \multicolumn{1}{|c|}{ Element } & Units & Value \\
\hline Aviaries number & & 1,035 \\
\hline Birds housed & & $24,056,866$ \\
\hline Bed amount in one year & {$[\mathrm{Kg}]$} & $316,107,219.24$ \\
\hline Average calorific value & {$[\mathrm{MJ} / \mathrm{Kg}]$} & 11,25 \\
\hline Gross energy potential & {$[\mathrm{MJ} / \mathrm{year}]$} & $3,556,206,216$ \\
\hline & {$[\mathrm{MW}]$} & 112,8 \\
\hline $\begin{array}{l}\text { Efficiency of conversion } \\
\text { system }\end{array}$ & {$[\%]$} & 30 \\
\hline Technical Energy Potential & {$[\mathrm{MW}]$} & 34 \\
\hline
\end{tabular}

\section{B. Finals Considerations}

Some factors may make the electricity generation system economically viable, since the aviary considered in this work has no major energy expenses. In this sense, one can look for alternatives to use of surplus electrical energy, such as connecting other loads to the system. Thus, it can be observed that with the surplus energy fifteen houses with average month consumption of 250 $\mathrm{KWh}$ can be supplied. Another option is to use biogas directly over burners to heat the chicken in the first days of life, since the fuel currently used for the poultry in question is firewood. Factors such as the carbon credits can also help make the project viable.

An important factor associated with this study is the environmental issue, where the poultry industry currently 
does not suffer so many pressures with regard to waste management. However, studies show that the mismanagement of poultry litter as fertilizer can cause problems in soil and water sources. This may indeed contribute to further study the appropriateness of digesters in aviaries for electric power generation, since the studies found actuality were made in a didactic manner, where it is not possible to establish parameters that indicate proper operation and management to must be taken with a large installation.

\section{Conclusion}

The importance of poultry production in the region clearly shows the need for studies that indicate an alternative to the correct destination of the poultry waste industry. Thus, this work reports the study of the energy potential from poultry-litter in southern Brazil.

The animal waste is an important biomass form, which may be used as a primary resource for electric power generation. The poultry litter has a considerable energetic potential, both for its calorific power as by the large amount of waste generated. Several types of technologies are being implemented in order to enable the conversion of this type of biomass in electricity energy. A biodigester, correctly installed in a poultry establishment uses the poultry litter as biomass and is able to repay at least $40 \%$ of energy expenses in the aviaries.

The poultry litter is used today as fertilizer, but can be applied as source primary to a system of electric power generation, in which the by-product generated in the process can also be applied to soil fertilization. It is noteworthy that the impacts generated by the by-product are lower than those of untreated waste. With this, the system of power generation will add great value to biomass.

The electricity in everyday life is essential and therefore the inclusion of new sources in the energy matrix is an important factor in ensuring the supply of this commodity so important for society. The renewable sources are even most important because they provide the comfort of electricity without causing major damage to nature.

One way to mitigate the environmental impact produced in the production of broilers is to use the waste to anaerobic production of biogas as fuel to generate electricity directly. The biogas generated from poultry litter can be used as a source of energy on the farm itself, its usage is in heaters to generate thermal energy used to heat the chicken at the beginning of the batch. The same gas can also be used as fuel for internal combustion engines to generate electricity. The effluents and solid wastes from the anaerobic fermentation process can be used as fertilizer for having a high content of protein, vitamins and minerals. In this sense, this study contributes with the use of the biomass for the electricity generation using poultry waste, presenting a more efficient uses of these wastes and reducing its impact on the environment.

\section{References}

[1] A. L. Mourad, v. S. Ambrogi, and S. M. Guerra. Potencial de utilização energética de biomassa residual de grãos. In:
Proceedings of the 5th Encontro de Energia no Meio Rural, Campinas, São Paulo, Brazil, 2004.

[2] R. V. D. Broek, A. Faaij, A. V. Wijk, Biomass combustion for power generation. Biomass and bioenergy, vol. 11, $\mathrm{N}^{\circ}$ 4, p. 271-281, Elsevier Science B.V 1996.

[3] J. Goldenberg, S. T. Coelho. Renewable energy -traditional biomass vs. modern biomass. Energy Policy, vol. 32, p. 711-714, Elsevier Science, 2004.

[4] D. Voivontas, D. Assimacopoulos, E. G. Koukios, Assessment of biomass potencial of power production: a GIS based method. Biomass and Bioenergy, vol. 20, p.1112, Elsevier Science B.V. 2001.

[5] Ministério de Minas e Energia. Resenha Energética Brasileira: Exercício de 2010, pp. 28. Maio de 2011. Available in: http://portalpch.com.br

[6] E. H. Fukayama. Quantitative and Qualitative Characteristics of the Litter of Broiler Under Different Reuses: Effect in the Production of Biogas and Organic Fertilizer. Doctoral Thesys, pp. 99, State University Paulista, Brazil, 2008.

[7] L. V. Cabral da Costa. Anaerobic Digestion of Litter of Broiler Associated with the Fertilizer Obtained Manure from Pigs: Biogas Production and Quality of Fertilizer. Master Thesys, pp. 89, State University Paulista, Brazil, 2009.

[8] E. O. Oviedo-Rondón. Tecnologias para mitigar o impacto ambiental da produção de frangos de corte. Revista Brasileira de Zootecnia, V. 37, pp. 239-252, 2008.

[9] A. Sordi, et al. Estimativa do potencial de geração de energia elétrica proveniente do uso dos resíduos da avicultura de corte na mesorregião oeste do Paraná. Revista Engenharia na Agricultura, Viçosa, v. 12, n. 4, pp. 316-321, 2004.

[10] J. Lucas Jr., M. B. Tânia. Aproveitamento de resíduos de indústria avícola para produção de biogás. Simpósio sobre resíduos da produção avícola, Statal University Paulista, pp. 27-43, São Paulo, Brazil, 2000.

[11] B. R. Bock. Poultry litter to energy: technical and economic feasibility. TVA Public Power Institute, Muscle Shoals, Alabama, 2004.

[12] J. R. Flora, C. Riahi-Nezhad. Availability of poultry manure as a potential bio-fuel feedstock for energy production. Southern Carolina, USA, 2006.

[13] R. P. Catarino, A. P. N. González, L. R. P. Oliveira. Optimization of Methane Production from Chicken Manure Bed. I International Symposium on Animal Waste Management.

[14] P. C. R. Lima. Biogás da suinocultura: uma importante fonte de geração de energia. Brasília, Brazil, October 2007.

[15] Instituto Brasileiro de Geografia e Estatística, IBGE. 2011. Available in: http://www.ibge.gov.br 